\title{
Who is fishing and how?: The case study of fishing communities in Cyprus through time
}

\author{
Maria Michael \\ PhD Candidate (HFF Studentship), University of Southampton, Southampton, UK
}

\begin{abstract}
This paper forms part of an ongoing $\mathrm{PhD}$ thesis, which attempts for the first time to gather all the available evidence related to fishing on Cyprus in a single body of evidence. It explores the tradition of fishing on the island from the Neolithic to the Early Christian periods. It mainly aims to determine the development of fishing technologies and to gain a more holistic understanding of the relationship between fishermen and their maritime cultural landscape. Consequently, this paper discusses the research background and the methodological approaches employed to achieve the aforementioned purposes.
\end{abstract}

\section{Key words}

Cyprus, Fishing, Fishing gear, Maritime Cultural Landscape.

\section{Introduction}

As Honor Frost mentioned a few decades ago (Frost, 1985: 169), the study of fishing technology and activity is neglected in Cyprus. Thus if someone attempts to explore fishing in Cyprus, they must be ready to face significant research gaps and problematic interpretations of finds. There are limitations that can be overcome if there is a willingness to answer the research question of whether or not Cypriots fished in the past.

Thus, the current research attempts to study the archaeological evidence of fishing technology (e.g. harpoons or spears; hooks; traps; stone, clay, and lead weights for nets or fishing lines; installations such as fish-tanks) and 
explore the reasons for their creation, alterations and developments through time (Fig. 1). Cyprus was chosen as a case study because the study of fishing technology and activity has not yet been examined in detail in its archaeological context (Fig. 2). A wide temporal span from prehistory to Late Antiquity has been adopted, distinguishing chronological, topographical, and typological patterns in the development of fishing in the archaeological context of Cyprus through several millennia.

In this research, published material from final reports of archaeological sites in Cyprus, archives of archaeological data relating to fishing technology and activity, fishbone assemblages, and written, iconographic, environmental, and ethnographic data have been used. Fieldwork is also being conducted with systematic recording of archaeological finds, which are the primary data of this research. Consequently, this study attempts to join for the first time the study of archaeological finds with icthyological data from archaeological sites in Cyprus. This icthyo-archaeological evidence will be combined with written, iconographic, environmental, and ethnographic data in order to gain a holistic understanding of fishing technology and activity in Cyprus through time.

In this paper, I firstly discuss the previous research on fishing in Cyprus, in order to present the main issues and considerations and to establish an effective background against which a new approach can create and develop. Secondly, the significance and aims of the on-going research are defined, and then the methodological approaches are briefly discussed. Finally, some preliminary conclusions are presented.

\section{Research Background: Issues and considerations in the study of fishing in Cyprus}

The research field of fishing has been understudied and left out of discussion for a long time within the archaeological context of Cyprus. The inability and indifference of some researchers in recording and interpreting finds relating to how fish were caught, and the lack of a proper methodological approach, are some of the main issues that hinder the holistic understanding of fishing activity in antiquity.

Archaeological finds related to fishing technology seems to be limited in different sites (e.g., Dikaios, 1961: 95; Christou, 1998a: 58-59, 63-64; Christou, 1998b: 67-68; Hadjisavvas, 2007: 63). Finds associated with fishing equipment are generally not included in a distinct section in final publications, but rather, are presented within the finds catalogues without differentiation from the other items, and they are rarely photographed (e.g., Gjerstad et al., 1937: 100; Dikaios, 1971: 651, 679, 717-718, 729; Chavane, 1975: 109-114, pl.31; Salles and Chavane, 1993: 333). In other cases, finds are not even presented in the final reports of an archaeological site, but scholars concluded in their final remarks that fishing activities were undertaken in the area based on archaeological finds (Hadjisavvas, 1997: 31).

Few analyses of archaeological faunal remains from Cyprus have been carried out (Karageorghis, 1970: 51, 305; Reese, 1989: 116; Tepe, 2012: 678). Fish remains are abundant in some sites and nonexistent in others. For instance, in the Neolithic site of Cape Andreas Kastros, more than 6,000 remains of bony fish were recovered (Desse and Desse-Berset, 1994), while only four unidentified fish bones were found from a Hellenistic basin at Kition-Bamboula (Desse, 1993: 104-105). The presence or absence of fish remains in some archaeological sites can be the result of many economic, social, religious, environmental, and climatic factors 
(among others), or of the archaeological methods used during their recovery in archaeological sites (e.g. BekkerNielsen, 2010: 187; Maarlevend, 2010). In Cyprus, the limited or non-existent usage of sieving in conjunction with the absence of precise and integrated reference collections seem to be the main reasons that affect the precise identification of fish species (Wilkins, 1953; Halstread, 1977).

The problematic presentation and analysis of evidence combined with the scant knowledge of methodological approaches can also lead to misinterpretation and incorrect classification. Frost (1985: 169-171) was probably the first archaeologist who identified and addressed this issue in the archaeological context of Cyprus. She attempted to distinguish three limestone weights from the archaeological site of Kition-Bamboula from similarly shaped stone anchors by comparing them with other archaeological finds related to fishing in the eastern Mediterranean. She also used ethnographic data of weighted fishing nets from Lebanon and iconographic evidence from Egypt (Fig. 3), in order to achieve a more integrated identification and reconstruction of these limestone weights (Frost, 1985: 172-173). Consequently, she attempted to arouse scholars' interest in this archaeologically neglected aspect of any maritime community, namely, its fishery. Frost worked to develop an innovative methodological approach, in order to correctly understand and accurately interpret its indicators.

Despite all her efforts, few scholars were interested in studying fishing as an aspect of Cypriot maritime communities. For instance, some scholars (Ohnefalsch-Richter, 1913; Michaelides, 1998; Egoumenidou and Michaelides, 2000) studied fishing activities and fish consumption by using mainly written and ethnographic sources without any systematic analysis of archaeological and ichthyofaunal data. Furthermore, they uncritically accepted the accuracy of the Cypriot folk saying, 'A hunter's bowl and a fisherman's plate are forty times empty and only one day full' (Egoumenidou and Michaelides, 2000: 112). As a result, they mainly concluded that fishing was a difficult profession and not lucrative, and in turn, that Cypriots did not choose it as their main occupation (Ionas, 2001: 217).

On the other hand, a recent article by the archaeologist Lindqvist (2016) presents a synthetic methodological approach. He examines and classifies the different kinds of fishing tackle recovered in archaeological finds along with fish remains and iconographic sources from the Late Bronze Age site of Hala Sultan Tekke. Although his work employs a holistic methodology and enriches the knowledge of fishing activities in this society, it concentrates only on a specific area and chronological period without any connection with other archaeological sites on the island or in the eastern Mediterranean.

Furthermore, the recent work of Knapp seeks to answer the question: 'What other evidence exists for seafaring, fishing, the exploitation of marine resources and related maritime matters?' (Knapp, 2018: 22). In order to answer this research question, a theoretical approach to the social and material aspects of the maritime world of the Bronze Age eastern Mediterranean has been combined with a broad analysis of the actual evidence from each of the Early, Middle, and Late Bronze ages (Knapp, 2018: 26-27, 59-61). Specifically, for Cyprus, he briefly discussed the finds from three sites (Kition, Enkomi and Hala Sultan Tekke), without any detailed analysis which might provide information about the fishing methods that Cypriots had developed during this specific chronological period, or the influence of fishing in their economic or social contexts (Knapp, 2018: 
151-153). Although this work provides a general view of the study of fishing in these specific chronological periods and regional context, it does not delve deeper into this research field.

To sum up, from the aforementioned works, it is clear that the archaeological evidence of how fish were caught has not been compiled in a publication or examined simultaneously with other evidence, such as fishbone assemblages, in order to understand whether Cypriots fished in the past. Furthermore, it seems that the study of fishing in Cyprus could be characterised historically as fragmentary and unequal in coverage and methods, but this view has improved recently and on a site-specific basis. However, a systematic study is required within the archaeological context of Cyprus.

\section{Significance and aims of the current research}

Consequently, the current research aims to be a systematic study of fishing technology and activity in the archaeological context of Cyprus from the Neolithic to the Early Christian periods ( $10_{\text {th }}$ millennium BC - mid 7 th century AD). It aims to combine all the available archaeological finds of fishing gear from terrestrial and underwater sites in an attempt to clarify whether Cypriots fished or not in the past. If they did indeed fish, then the goal is to acquire a better general understanding of the formative phases of fishing activity on the island through time. This systematic recording of archaeological artefacts will improve future identifications and form a basis of a comprehensive typological classification through time. It will also help us to understand the reasons for the existence, alteration, or absence of fishing activities in certain chronological periods or regions.

Furthermore, the identified fishbone assemblages, the iconographic and written sources, and the ethnographic information serve as supporting classes of evidence, in order to determine the development of fishing technologies diachronically and to discover if and when the fishing activities had an influence on the economy and the daily life of the communities of the island. Moreover, the parallel examination of ichthyo-archaeological evidence with ecological and environmental data will assist us in understanding how the ancient physical Mediterranean environment determined the presence or absence of fishing activities in the maritime landscape, and to clarify whether fishermen utilised their knowledge of the environment and animal behaviour to their benefit (Marzano, 2013: 2). Finally, this research also aims to re-consider the methodological approaches applied to reconstructing fishing activities and techniques in other regions in the Mediterranean basin and beyond, in order to establish innovative methodological approaches in the archaeological context of Cyprus.

\section{Methodological Approach}

In order to achieve the aforementioned objectives, a methodology is needed, which is divided into four steps. Firstly, collection of the data, which mainly includes archaeological finds related to fishing techniques, fishbone assemblages, iconographic and written sources, environmental features of fishing grounds, biological characteristics of different fish species, and ethnographic data (Fig. 4). The collection of data is mainly based on desk-based research and fieldwork in the storerooms of the museums of Nicosia, Larnaca, Limassol, Paphos and Polis Chrysochous. 
Secondly, the systematic recording of the data leads to the creation of a database, where the evidence of fishing gear, identified fishbone assemblages, and the chosen iconographic and written sources are archived. This will be the first time that all of the evidence for fishing in ancient times in Cyprus will be gathered together in a single body of evidence.

Thirdly, the methodological framework of this research includes the creation of distribution maps using ArcGIS software, in order to visualise the evidence regionally and chronologically. This will help to distinguish temporal and territorial patterns, which may shed light on the reasons for the presence or absence of fishing activities in some periods or areas respectively.

Fourthly, data analysis is divided into systematic and comparative analyses, in order to holistically interpret the evidence presented. The systematic analysis aims to examine and interpret the selected data using both qualitative and quantitative research techniques. The employment of statistical methods in this research is to visualise the numbers of archaeological sites where archaeological and ichthyofaunal data were recovered through graphs, pie charts and tables, and to justify conclusions. This will mainly help explain the temporal and spatial distribution of evidence across the island.

Parallel with the systematic analysis of data, a comparative analysis will been applied. The comparative analysis mainly aims to draw comparisons between the different chronological periods, in order to provide a typological analysis of fishing gear from different chronological periods. Furthermore, the archaeological and ichthyofaunal data will be compared with ethnographic data to draw analogies, which will lead to holistic interpretation and reconstruction of fishing techniques and activities. Finally, this data will be compared with evidence from other regions in the eastern Mediterranean to identify correlations and to integrate Cypriot evidence within the wider context of the eastern Mediterranean, where ancient fishermen worked and interacted.

\section{Presentation and discussion of preliminary results}

As already mentioned, this report is part of an on-going $\mathrm{PhD}$ thesis. However, some preliminary results can be discussed here. Thus far, 141 archaeological sites dated to various chronological periods have been examined, but only 67 archaeological sites provide archaeological and faunal data related to fishing activities (Fig. 5). Finds of fishing gear have been recovered in only 16 sites, while fishbone assemblages have been recovered in 31 sites. In 17 sites, fish remains have been found with finds of fishing gear, and in three Roman/Early Christian sites, fish pools were found. Consequently, the opinion that Cypriots did not engage in fishing activities over time seems to be negated, as the archaeological and faunal evidence from Cyprus establish the presence of fishing activities in its maritime landscape.

However, it is obvious that a huge number of fish remains from archaeological sites are unidentified. Only 22 sites have provided identified fishbone assemblages that include different fish species caught in different periods. Furthermore, it seems that a plethora of fish remains come from the earlier periods, while the amount of fish remains from later periods decreases sharply (Fig. 6). This might be attributed to methodological, environmental, socio-economical, or historical factors, among others, which will be further clarified in the next steps of the project. 
Regarding the finds of fishing gear, the highest amount of finds are fish hooks and net weights, but they are scattered regionally and chronologically in various archaeological sites. It also seems that earlier periods provide less evidence than the latest one (Fig. 7). Furthermore, through analysis of faunal, environmental, and ethnographic evidence, it is possible to definitively establish the function of other fishing techniques, such as traps, and to confirm that they did not survive in the archaeological record due their perishable nature. Consequently, their absence in the archaeological record does not prove that Cypriots did not use them in the past.

In conclusion, regarding the preliminary analysis of archaeological finds and fishbone assemblages, it seems that the evidence is more prominent from the Neolithic, Late Bronze Age and Hellenistic-Roman periods. The majority of identified fishbone assemblages are dated to the Neolithic period, but the finds of fishing gear are minimal compared with other periods. The amounts of archaeological and ichthyological data seem to be equal in the Late Bronze Age period. Finally, the majority of finds relating to fishing activities are from the HellenisticRoman period, but identified fishbone assemblages are fewer than in earlier periods. Consequently, these chronological patterns can support the focus of the on-going $\mathrm{PhD}$ research on these chronological periods.

\section{Conclusion}

To conclude, according to the research background and the preliminary results of the on-going research, it seems that the study of fishing technology and activity is a neglected field in the archaeological context of Cyprus. A systematic recording of ichthyo-archaeological evidence and a multi-disciplinary methodological approach is needed, in order to better understand the development of fishing technologies, and to gain a more holistic appreciation of the relationship between Cypriot fishermen and their maritime cultural landscape. Consequently, this is the main purpose that this on-going $\mathrm{PhD}$ thesis strives to accomplish.

\section{Acknowledgements}

I would like to sincerely thank my supervisors, Dr. Julian Whitewright and Dr. Jaco Weinstock, who always support me. This work would not have been possible without the endless support of the Honor Frost Foundation, and Dr. Lucy Blue. I am also grateful to the Cypriot Department of Antiquities, all directors of archaeological excavations, and David Reese for granting access to the archaeological finds related to fishing. Thanks to CAARI as well for allowing me to use its premises when needed. Finally, immense gratitude also goes to my friends/colleagues, and specifically to Naseem Raad and Ziad Morsy, for their good collaboration and support during the MAGS 2019 symposium.

\section{Reference List}

Bekker-Nielsen, T., 2010, Fishing in the Roman World, in T. Bekker-Nielsen and D. B. Casasola (eds), Ancient Nets and Fishing Gear. Proceedings of the International Workshop on "Nets and Fishing Gear in Classical Antiquity: A first approach" Cadiz, November 15-17, 2007, 187-204. Aarhus: Aarhus University Press. 
Chavane, M.-J., 1975, Pêche, in M.-J. Chavane, Salamine de Chypre VI. Les Petites Objects, 109-114. Paris: De Boccard.

Christou, D., 1998a, Annual Report of the Department of Antiquities for the year 1992. Nicosia.

Christou, D., 1998b, Annual Report of the Department of Antiquities for the year 1993. Nicosia.

Desse, J., 1993, Les vestiges osseux du basin 417, in J.-F. Salles, Kition-Bamboula IV. Les Niveaux Hellénistiques, 103-105. Paris: Editions Recherche sur les Civilisations.

Desse, J., and Desse-Berset, N., 1989, Les poissons de Khirokitia (campagnes 1983, 1984 et 1986), in A. Le Brun (ed.), Fouilles Récentes à Khirokitia (Chypre) 1983-1986, 223-233. Paris.

Desse, J., and Desse-Berset, N., 1994, Osteometry and fishing strategies at Cape Andreas Kastro, Cyprus ( $8_{\text {th }}$ millennium BP), in W. Van Neer (ed.), Fish Exploitation in the past, Proceedings of the 7th meeting of the ICAZ fish remains working group, 69-79. Tervuen.

Dikaios, P., 1961, The Swedish Cyprus Expedition: The Stone Age in Cyprus. Vol. IV Part 1A. Lund.

Dikaios, P., 1971, Enkomi: Excavations 1948-1958, Volume II, Chronology, Summary and Conclusions, Catalogue, Appendices. Mainz am Rhein: Verlag Phillip von Zabern.

Egoumenidou, E. and Michaelides, D., 2000, Gathering, hunting, fishing. The procurement of food from the non-domesticated animal kingdom in Cyprus through the ages, in P. Lysaght (ed.), Food from Nature. Attitudes, Strategies and Culinary Practices. Proceedings of the 12th conference of the International Commission for Ethnological Food Research, Umea and Frostviken, Sweden, 8 - 14 June 1998, 111-120. Uppsala: The Royal Gustavus Adolphus Academy for Swedish Folk Culture.

Frost, H., 1985, Appendice 2: Fishing Tackle: Three Limestone Weights, in M. Yon, Kition-Bamboula 3. Le Sondage L-N 13 (Bronze récent et géométrique I), Vol.56, 169-171. Paris: Maison de 1' Orient Méditerranéen. Gjerstad, E. et al., 1937, The Swedish Cyprus Expedition. Finds and results of the excavations in Cyprus 1927 - 1931. Vol.III: Text. Stockholm.

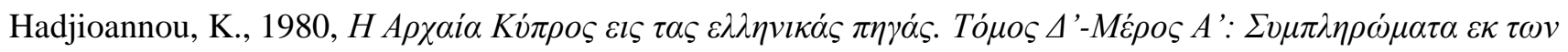

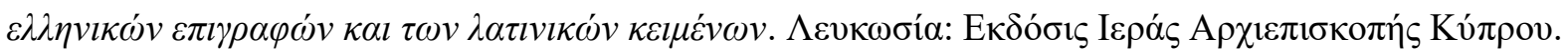

Hadjisavvas, S., 1997, Agia Napa: excavations at Makronisos and the archaeology of the region. Nicosia: Department of Antiquities.

Hadjisavvas, S., 2007, Annual Report of the Department of Antiquities for the year 2001. Nicosia.

Halstread, P., 1977, A Preliminary Report on the Faunal Remains from Late Bronze Age Kouklia, Paphos. Report of the Department of Antiquities, Cyprus, 261-275.

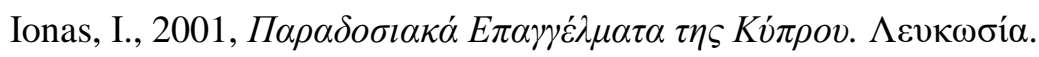

Karageorghis, V., 1970, Excavations in the Necropolis of Salamis II (Text). Vol.4. Nicosia: Department of Antiquities.

Knapp, B., 2018, Seafaring and Seafarers in the Bronze Age Eastern Mediterannean. Sidestone Press. [Online] Retrieved from https://www.sidestone.com/books/seafaring-and-seafarers-in-the-bronze-age-easternmediterranean. 
Lindqvist, A., 2016, A study of fishing methods used at Hala Sultan Tekke during the Late Bronze Age, in G. Bourogiannis and Ch. Muhlenbock (eds.), Ancient Cyprus today museum collections and new research, 239248. Uppsala: Åströms Förlag.

Maarlevend, T. J., 2010, Fish and "Chips of Knowledge": Some Thoughts on the Biases of the Archaeological Record, in T. Bekker-Nielsen and B. D. Casasola (eds.), Ancient Nets and Fishing Gear. Proceedings of the International Workshop on "Nets and Fishing Gear in Classical Antiquity: A first approach" Cadiz, November 15-17, 2007, 257-275. Aarhus: Aarhus University Press.

Marzano, A., 2013, Harvesting the Sea. The Exploitation of Marine Resources in the Roman Mediterranean. Oxford: Oxford University Press.

Michael, M., 2018a, The Hellenistic metallic artefacts found in Amathus harbor, in J.-Y. Empereur (ed.), The Hellenistic Harbour of Amathus Underwater Excavations, 1984-1986. Volume 2. Artefacts found during excavation, 79-118. Athens: École française d' Athènes.

Michael, M., 2018b, The Late Roman metallic artefacts found in Amathus harbor, in J.-Y. Empereur (ed.), The Hellenistic Harbour of Amathus Underwater Excavations, 1984-1986. Volume 2. Artefacts found during excavation, 191-196. Athens: École française d' Athènes.

Michaelides, D., 1998, Food in ancient Cyprus, in P. Lysaght (ed.), Food and the Traveller: migration, immigration, tourism and ethnic food. Proceedings of the 11 th Conference of the International Commission for Ethnological Food Research, Cyprus, June 8-14 1996, 22-43. Nicosia.

Ohnefalsch-Richter, M., 1913, Greek Customs and Mores in Cyprus. Berlin.

Papademtriou, E., 1999, Cyprus Folk Art. The Cyprus Folk Art Museum - Society of Cypriot Studies. Nicosia: Cultural Centre of the Popular Bank.

Reese, D. S., 1989, A fish bone from Kazaphani. (Appendix VI), in I. Nicolaou and K. Nicolaou, Kazaphani. A Middle/Late Cypriot Tomb at Kazaphani-Ayios Andronikos: T. 2A, B. Nicosia: Department of Antiquities.

Salles, J.-F. and Chavane, M.-J., 1993, Chapter XIV: Les petits objects, in J.-F. Salles, Kition-Bamboula IV. Les Niveaux Hellénistiques, 81-346. Paris: Editions Recherche sur les Civilisations.

Tepe, E., 2012, Zooarchaeological analysis of material from cisterns STR 1/96-97 and HA/NEH 2.16.3, in Nea Paphos. Polish Archaeology in Mediterranean 21, 677-689.

Wilkins, G., 1953, Shells from Khirokitia and Erimi, in P. Dikaios, Khirokitia: final report on the excavations of a Neolithic settlement in Cyprus, on behalf of the Department of Antiquities, 438-440, London: Oxford University Press. 


\section{Figures}
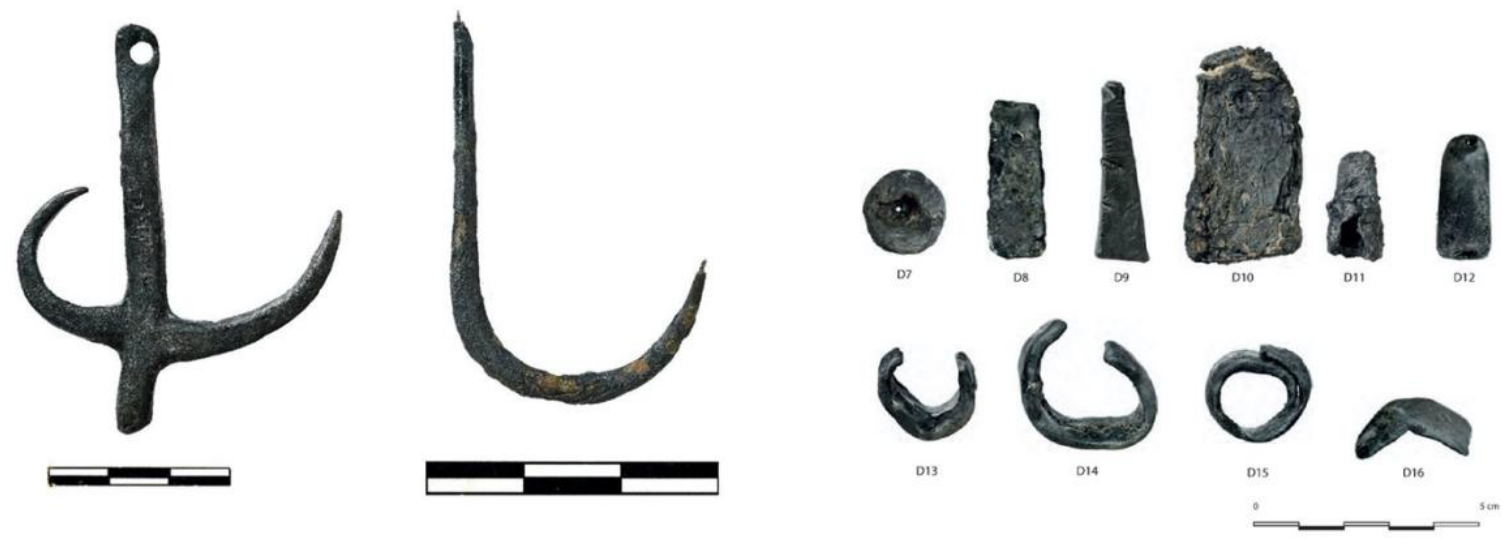

Figure 1: Fishing gear: Fish hooks and weights. (Michael, 2018a: 109, fig. 3, ㄷ A. Athanasiou, Archives of École française d' Athènes).

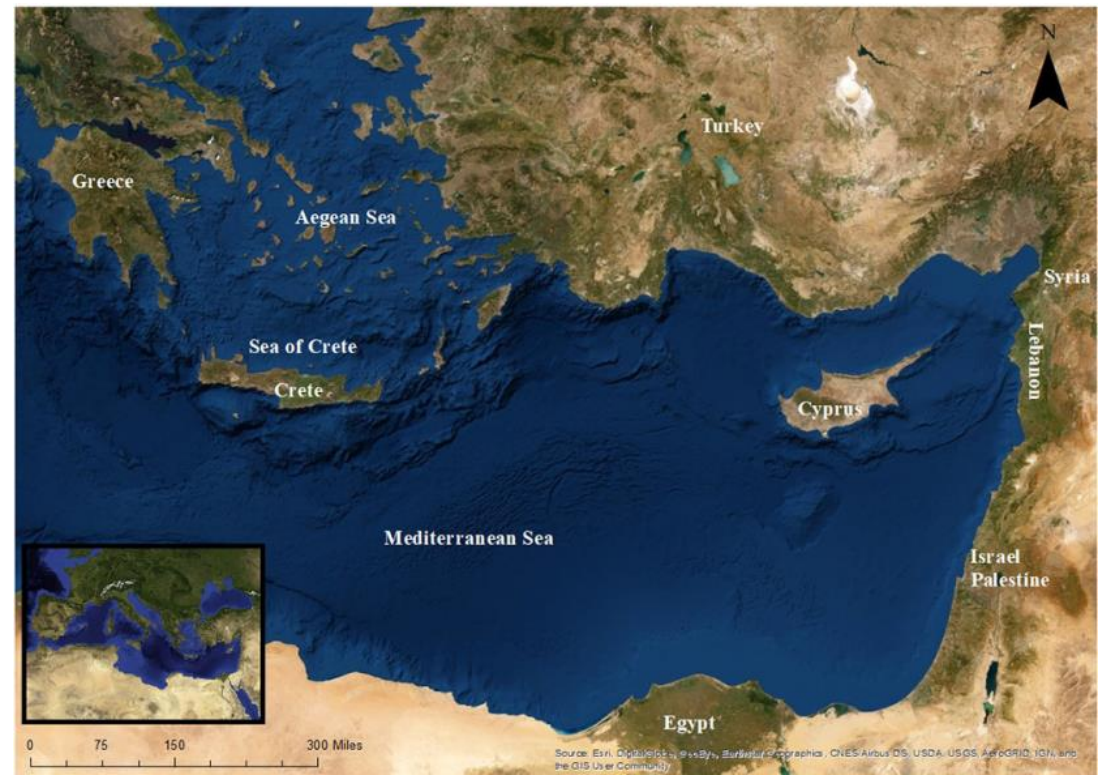

Figure 2: Map of Cyprus and the eastern Mediterranean. (ㄷ M. Michael; Source of the basemap: Esri, DigitalGlobe, GeoEye, Earthstar Geographics, CNES/Airbus DS, USDA, USGS, AeroGRID, IGN, and the GIS User Community). 

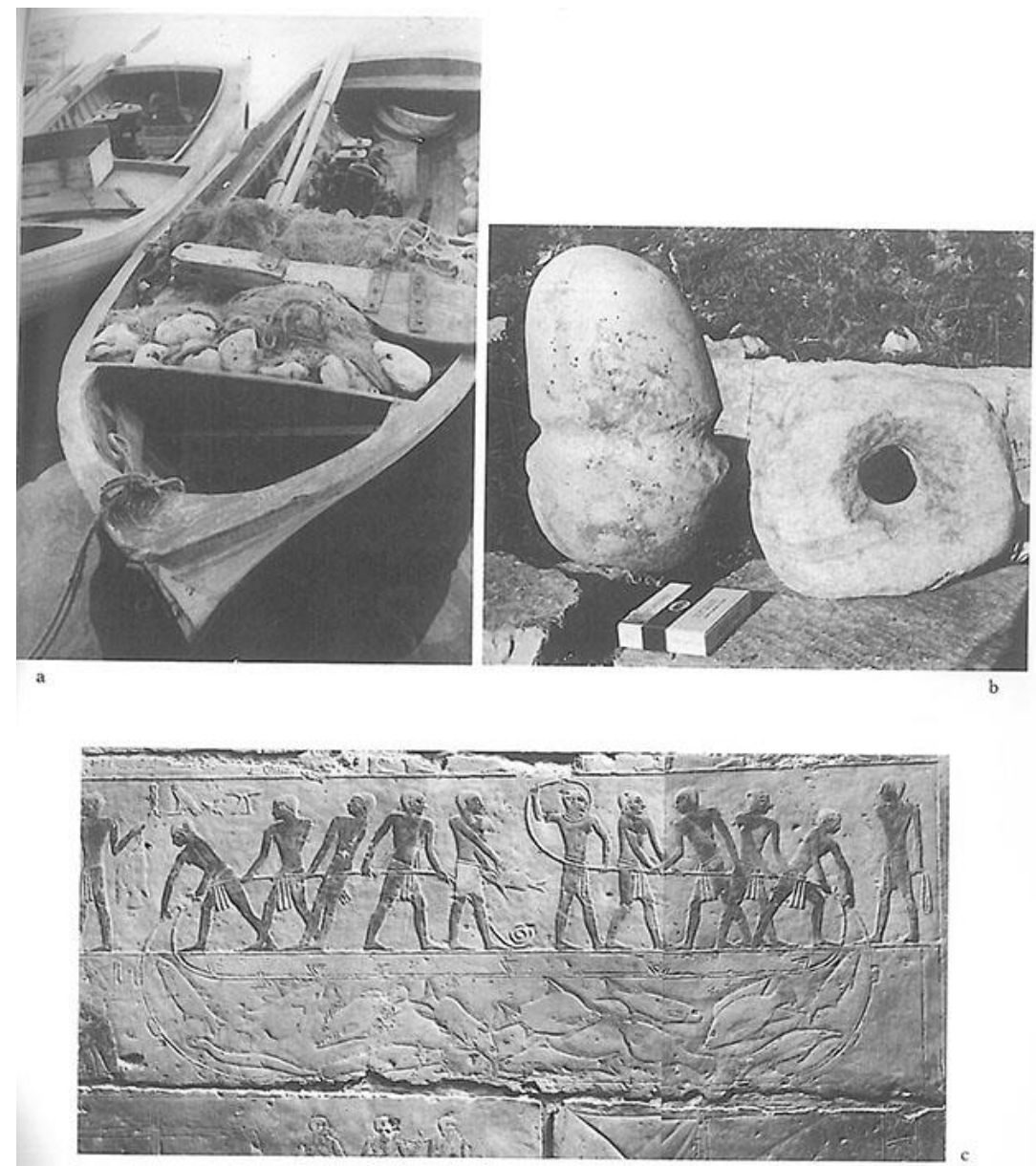

Figure 3: Ethnographic data of weighted fishing nets from Lebanon and iconographic evidence from Egypt were considered to achieve a more integrated identification and reconstruction of three limestone weights from the archaeological site Kition-Bamboula. a) Contemporary Lebanese fishing boat with weighted net in the bow. b) Two fishermen's weights from Byblos. c) Detail from the mastaba of Akhetep (Louvre) (Frost, 1985: 173, fig. 79). 


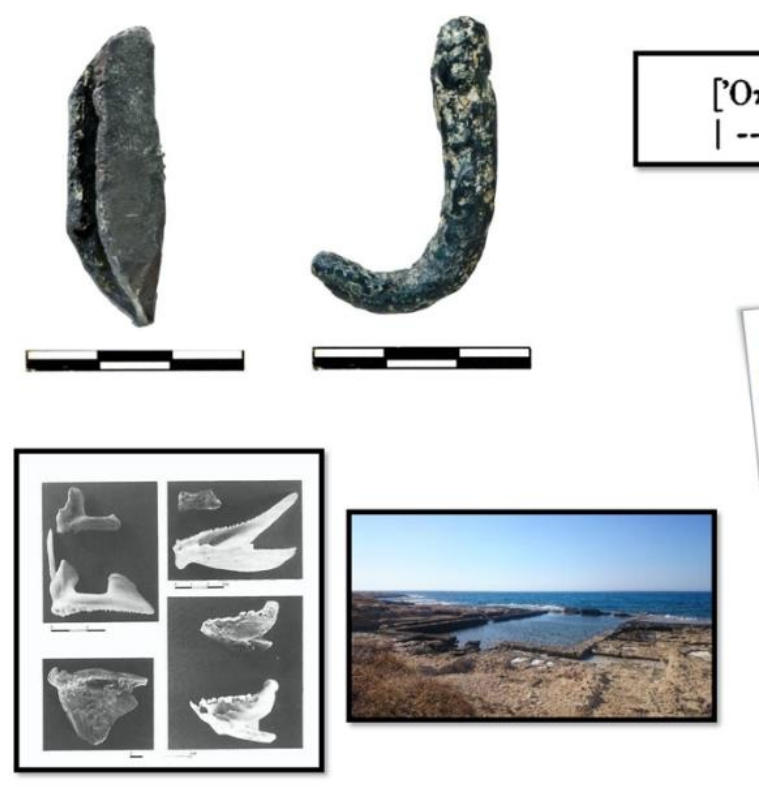

Archaeological Finds: Fishing Gear and Fishbone Assemblages
Written Sources

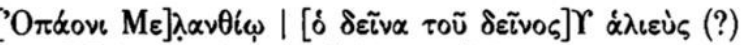

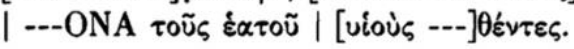

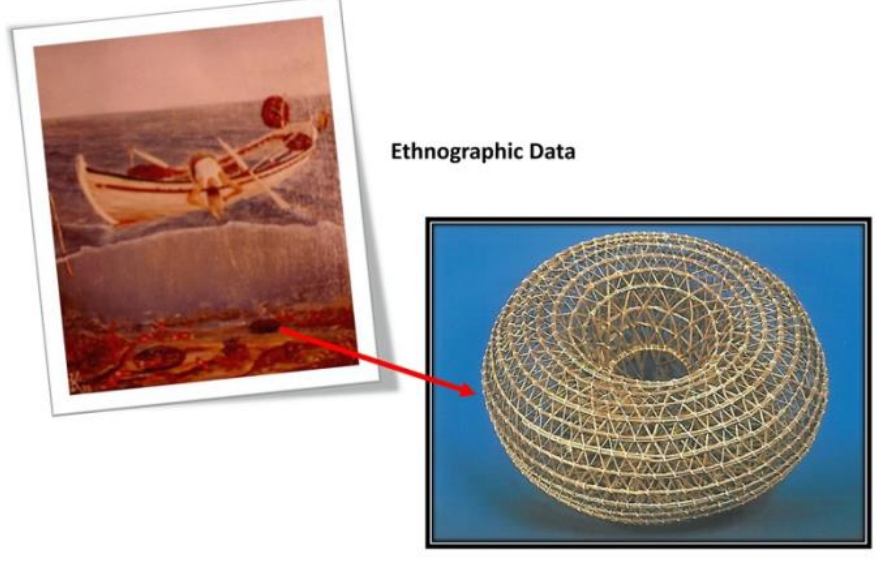

Figure 4: Dataset of the purposes of the current research. (@) M.Michael; Source of the archaeological finds: Michael, 2018b: 195, fig. 1, (C A. Athanasiou; Desse and Desse-Berset, 1989: 225, Planche XX / Source of the written sources: Hadjioannou, 1980: 89 / Source of the ethnographic data: @ A. Keleshis; Papademetriou, 1999: 75, fig. 100).

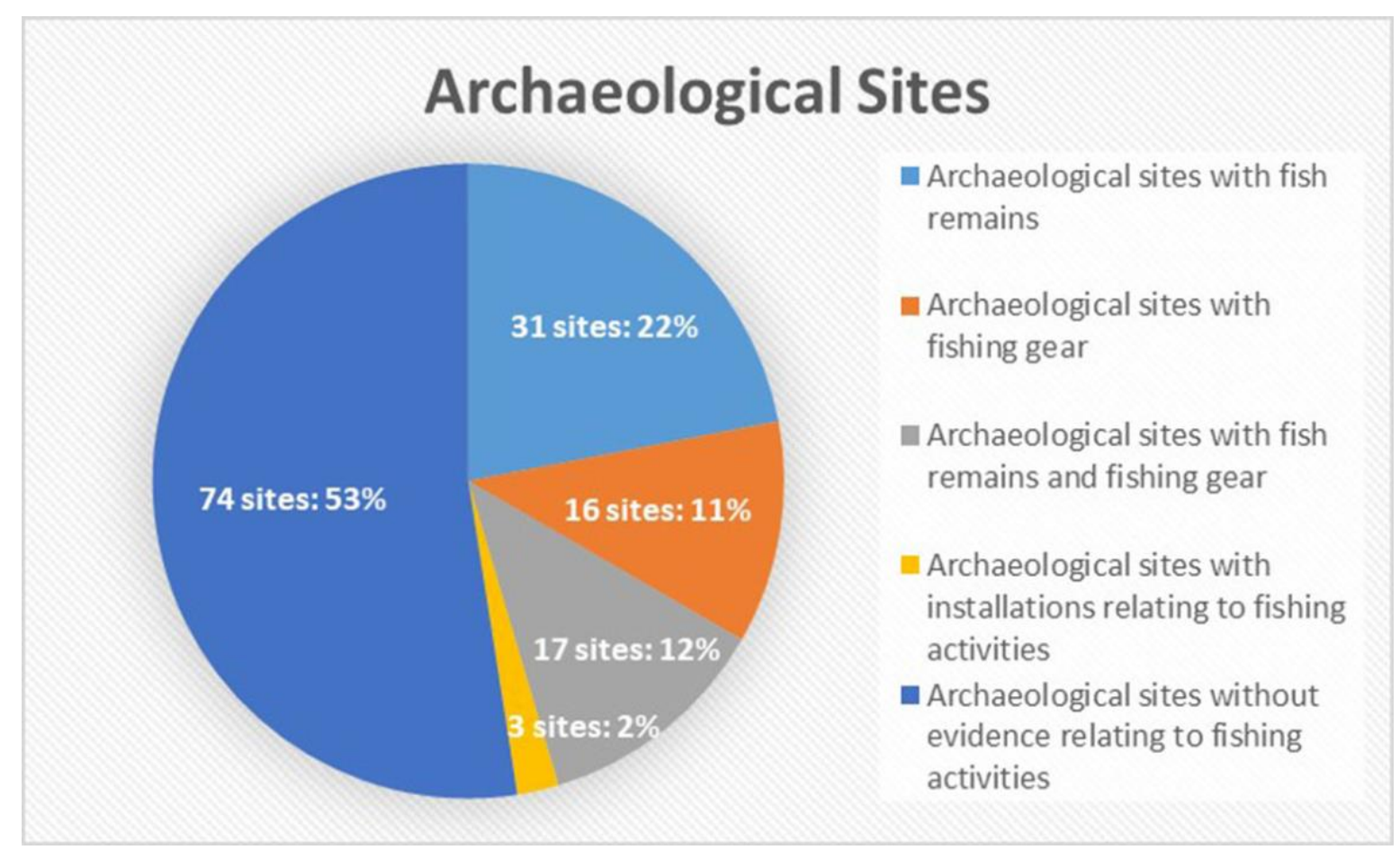

Figure 5: A pie chart shows the absence, existence, or coexistence of fish remains and finds of fishing gear in archaeological sites dated to various chronological periods. (@ M. Michael). 


\section{Fish Remains}

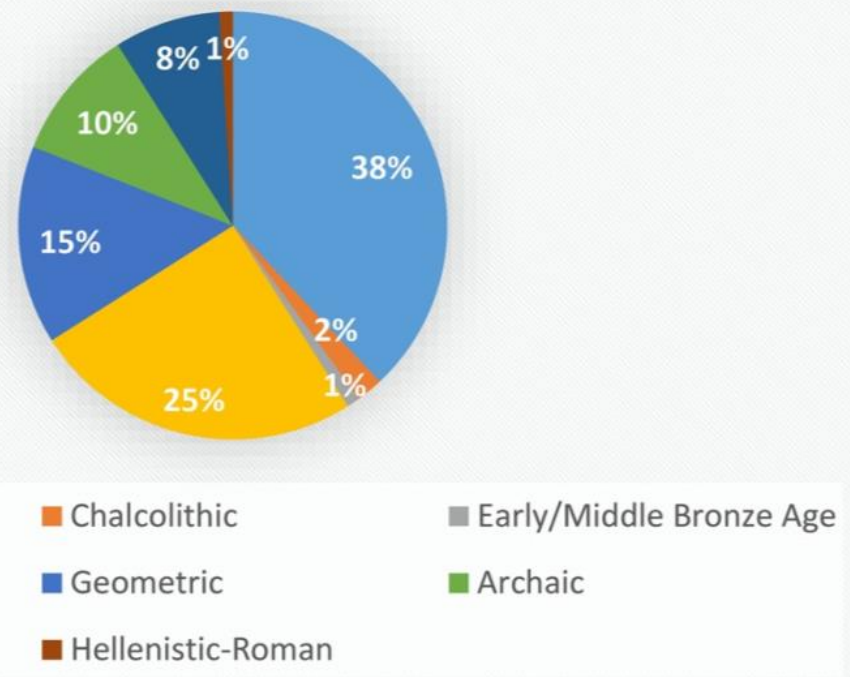

Figure 6: A pie chart shows the chronological distribution of fishbone assemblages in Cyprus. (@ M. Michael).

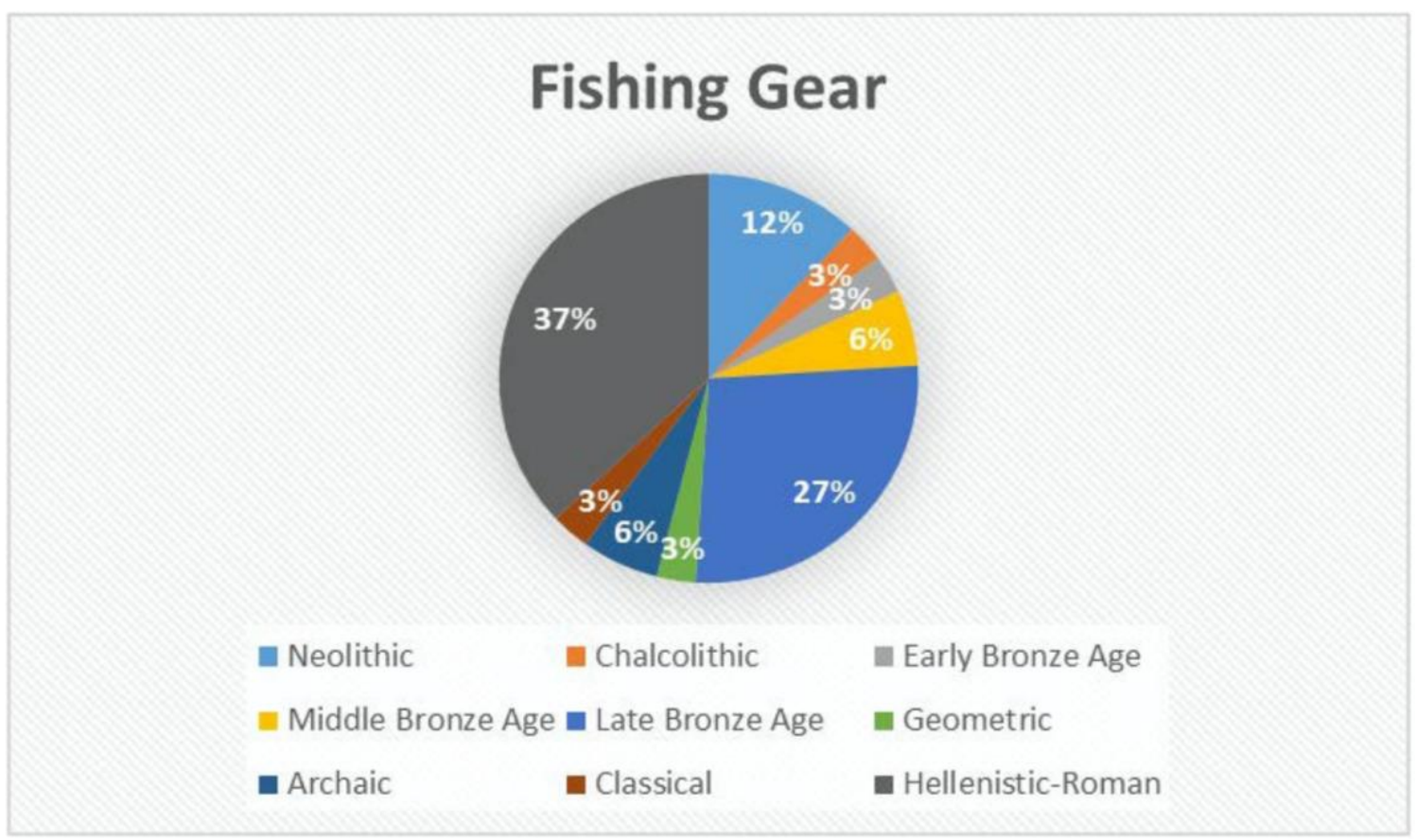

Figure 7: A pie chart shows the chronological distribution of finds of fishing gear in Cyprus. (@ M. Michael). 